\title{
Role of doctors in epidemics: historical perspectives and implications for COVID-19
}

\author{
Donatella Lippi ${ }^{1} \cdot$ Raffaella Bianucci $^{2,3,4} \cdot$ Simon Donell ${ }^{5}$
}

Received: 12 April 2020 / Accepted: 17 April 2020 / Published online: 10 May 2020

(c) Società Italiana di Medicina Interna (SIMI) 2020

\section{Dear Editor,}

By the latter half of the 20th century, the civic and medical response to epidemics were improved from previous times by changes in organisation and coordination, different methods of upscaling healthcare staff, and modern means of prevention and health surveillance. As a result, in 1988, Daniel M. Fox [1], Professor of Humanities in Medicine at the State University of New York, commented that the changes in the natural history of epidemics had become a topic exclusively of historical interest. However epidemics since, and now Covid-19, show this to have been a false hope.

The response of doctors to epidemics in the past has been mixed. In $163 \mathrm{CE}$, when the Antonine plague (smallpox?) broke out in Rome, Galen left the city and returned to Pergamum. In 1665 Thomas Sydenham abandoned London when it was being devastated by the plague [2]. The Physician was the top of the professional hierarchy. If he remained in the city, he would send a surgeon (a practitioner of lower rank) to visit the sick. The surgeon would describe the symptoms through the window of the house and the Physician would pronounce his opinion and prescribe the treatment [2].

Raffaella Bianucci

raffaella.bianucci@unito.it

1 Department of Experimental and Clinical Medicine, University of Florence, Florence, Italy

2 Warwick Medical School, Biomedical Sciences, University of Warwick, Coventry, UK

3 Legal Medicine Section, Department of Public Health and Paediatric Sciences, University of Turin, Corso Galileo Galilei 22, 10126 Turin, Italy

4 UMR 7268, Laboratoire d'Anthropologie Bio-culturelle, Droit, Etique \& Santé (Adés), Faculté de Médecine de Marseille, Marseille, France

5 Norwich Medical School, University of East Anglia, Norwich, UK
However epidemics were frequent and medicine remained an almost exclusive, elitist monopoly. For this reason they became an opportunity for professional success. The doctor, recruited on these occasions, became an important person. The authorities provided doctors with protective measures such as spongia olfacienda and clothing treated with aromatic substances. They had particularly attractive contracts. In Geoffrey Chaucer's Canterbury Tales the very learned doctor "kept what he had gained during the plague, because gold in medicine is a cordial. That's why he loved gold so much" [3].

The gold-pestilence link goes far beyond Chaucer's irony and interest in the representation of 14th century society. It offers the opportunity to reflect on the obligations of the doctor (and nowadays other healthcare professionals) in times of epidemics: express consent, implicit consent, special training, reciprocity, codes and oaths. Doctors have a duty to treat the sick, at the cost of their lives. This was considered when HIV-AIDS first appeared. When it came under control the question returned to being purely "academic". However, with the advent of rapidly spreading infectious diseases, such as SARS, the Ebola virus, avian influenza, antibiotic-resistant tuberculosis, the speed of spread of an influenza outbreak showed that a virus has the potential to overwhelm and block an entire health system, creating unprecedented situations, in a way in which AIDS has never done [3].

Doctors are guided by a code of ethics that was traditionally based around the Hippocratic Oath [4], which encourages them to "provide assistance in urgent cases and to make myself available to the competent authority, in case of public disaster". In return for treating patients in epidemics, they have received generous salaries with progressive increases, reimbursement of expenses, and, if from abroad, granting of citizenship [1].

In 1793, when an epidemic raged through Philadelphia, Benjamin Rusch continued his medical practice by visiting 100 patients in a day, until a French doctor arrived. He was a refugee from Santo Domingo. He found professional success 
from being recruited for this emergency [1]. Fifty years later, in New Orleans, another yellow fever epidemic brought together a group of young businessmen who recruited doctors seeking fame and work, guaranteeing their reputation and money [1].

Over the course of time, these models of civic and medical response to epidemics have been overcome by organisational changes, different methods of recruitment, and modern means of prevention and health surveillance. Pandemics seemed a distant memory. Dealing with the Covid-19 outbreak, and using the terminology of war reminds us of the meaning of the Monument to the Fallen Doctor, inaugurated in the aftermath of the First World War which resides inside the Military Health School of Florence [5]. The monument was made from the bronze of Austrian cannons (the same material was used to forge the medals for the soldiers) and paid tribute to all those doctors and health care workers, who had put themselves at the service of the country, and died in fulfilment of their duty. The doctor, wrote the author and Ferrarese sculptor Arrigo Minerbi, is "the most human of the heroes" [5].

The apocalyptic landscape accompanying the COVID-19 pandemic with doctors in quarantine, sick doctors, and dead doctors, reminds us of the risks that they take on. In addition to the toll on the health service of large numbers of sick patients infected by the organism is the secondary effects on all other medical conditions by the cancellation of other activities such as specialist visits, interventions, operations, and screening.

Medical patients will have their diseases less well monitored and may worsen over time. Surgical patients will have delayed operations, or if urgent e.g., a trauma patient, treated non-operatively, or by a different technique to avoid using power tools, which create an aerosol that endangers all the operating room staff [6]. Body exhaust suits mitigate this risk, but require operating rooms built for their use, and the protective gear to be available. This will raise the burden of disease in the general population and will have an adverse effect on the Health Service when the pandemic is under control.

We have a great understanding of what infections are and the skills and technology to overcome them. However, still doctors, and all healthcare professionals (reflecting the multidisciplinary nature of disease management) take risks when dealing with pandemics. In these circumstances "gold" is not necessary, but protective measures and equipment, which are known to be effective, are essential. Healthcare professionals have a duty to treat the sick. Governments, on behalf of their people, have a duty to protect them.

Author contribution All authors had access to the data and a role in writing the manuscript.

Funding None.

\section{Compliance with ethical standards}

Conflict of interest The authors declare that they have no conflict of interest.

Human and animal rights statement We did not work on human patients nor on animals.

Informed consent We did not need informed consent.

\section{References}

1. Fox DM (1988) The politics of physicians' responsibility in epidemics: a note on history. Hastings Cent Rep 18:5-10

2. Malm H, May T, Francis LP, Omer SB, Salmon DA, Hood R (2008) Ethics, pandemics, and the duty to treat. Am J Bioeth 8:4-19

3. Geoffrey Chaucer. The Canterbury Tales. A reader-friendly edition put into modern spelling by Michael Murphy. New York, Brooklin College. https://academic.brooklyn.cuny.edu/webcore/ murphy/canterbury/. Accessed 26 March 2020

4. Lippi D, Gensini GF, Conti AA (2003) Charter on medical professionalism: putting the charter into practice. Ann Intern Med 138:852-853

5. Lippi D. (2015) La Medicina e gli ospedali fiorentini durante la grande guerra. In: Perfetti F, editor. Atti del convegno Niente fu più come prima. La grande guerra e l'Italia cento anni dopo: 13-14 marzo 2015; Firenze. Firenze: Polistampa. 219-230

6. COVID-19: Good Practice for Surgeons and Surgical Teams. Royal College of Surgeons 2020: 3 April. https://www.rcseng.ac. uk/standards-and-research/standards-and-guidance/good-pract ice-guides/coronaviruses/covid-19-good-practice-for-surgeonsand-surgical-teams/. Accessed 12 Apr 2020

Publisher's Note Springer Nature remains neutral with regard to jurisdictional claims in published maps and institutional affiliations. 